\title{
Regional Support of Small Business in the Agriculture Sphere of the Krasnoyarsk region
}

\author{
Alena Rozhkova \\ Krasnoyarsk State Agrarian University \\ Krasnoyarsk, Russia \\ alena-mf@mail.ru
}

\author{
Julia Olentsova \\ Krasnoyarsk State Agrarian University \\ Krasnoyarsk, Russia \\ tutor.eng@yandex.ru
}

\begin{abstract}
Small and medium businesses play a special role in the development of the agro-industrial complex of the country and individual regions. Small business is an important part of the market economic system; small businesses operate in almost all sectors of the economy. Thanks to flexibility and adaptability, small businesses can produce goods and services that big businesses produce irrationally. The developed sector of small business has not only evident economic, budgetary and social significance, but also contributes to increasing the level of social responsibility and economic initiative in society, the development of its human capital.

The article presents the material about the state of small business in the sphere of agriculture in the Krasnoyarsk region. The functioning problems of small businesses in the agricultural sector of the region are considered. Support measures of small and medium agribusiness in the Krasnoyarsk region are defined.
\end{abstract}

Keywords: entrepreneurship in agriculture, agro-industrial complex, regional support, small and medium business, Krasnoyarsk region

\section{INTRODUCTION}

Agro-industrial complex (AIC) is one of the largest intersectoral complexes, combining several economic sectors aimed at the production and processing of agricultural raw materials, as well as obtaining agricultural products for final consumption. The structure of the agro-industrial complex includes agriculture and industrial sectors directly associated with it - transportation, storage, processing of agricultural raw materials and products, and bringing to retail and wholesale buyers [1]. The chemical and machine-building industries are also closely connected with the agricultural sector.

Analyzing the situation of modern market conditions, it can be argued that a single whole economy of businesses [2], that are part of the agro-industrial complex, is absent. The complexity of the AIC functioning is largely the cause of the problems that arise, and also affects inter-sectoral relations. This problem needs to be eliminated, as agriculture is one of the main products consumers in other areas, creates a large number of jobs for citizens.
The solution to this problem can be cooperation with business entities. Because it is the business entities, thanks to their mobility and flexibility, quickly and timely adapt to new market requirements, contribute to the strengthening of existing links, functionally arising between different branches of human activity.

Modern business entities, especially its small and medium representatives, are given special importance in creating processes of stable development for the regional economy.

The formation of small and medium businesses in the agro-industrial complex is a complex, systemic, complex task, the solution of which depends on the diversity and combination of economic, institutional, social and other factors and conditions [3].

\section{MethodS AND RESUlTS}

According to the unified register of small and medium businesses as of April 1, 2019, 6.1 million small and medium businesses have been registered and operate in the Russian Federation, employing more than 16 million people, which is $25 \%$ of the total number of people employed in the economy. Small businesses make up $4.32 \%$ of the total number of small and medium-sized businesses.

The share of small agricultural businesses in Russia as a whole is about $20 \%$, while in the structure of GDP of developed countries is $50 \%$. At the same time, its value in some districts and subjects of Russia differs significantly from the average value. The territorial location of Russia has led to the creation of large agricultural businesses and very small farms and household farmsteads, while the medium businesses, designed to ensure the interconnection of large and small agro-industrial business, is only increasing [4-6].

Today, Federal and regional authorities pay considerable attention to the effective development of small and medium businesses, but their solution is not fast enough and contradictory. Often, cooperation between the state authorities and small and medium businesses is carried out in terms of 
financing, planning, development, construction, modernization, reconstruction and operation of all kinds of relevant infrastructure facilities based on the risk sharing between business and the state.

Activities in the field of agricultural business are significantly different from other types of business activities carried out by economic entities in order to make a profit.

The main indicators of small and medium businesses in the agricultural sector in 2000-2017 are given in table I.
TABLE I. THE MAIN INDICATORS OF SMALL AND MEDIUM BUSINESSES IN THE AGRICULTURAL SECTOR IN 2000-2017

\begin{tabular}{|c|c|c|c|c|c|c|c|}
\hline $\begin{array}{c}\text { AIC } \\
\text { segments }\end{array}$ & 2000 & 2005 & 2010 & $\begin{array}{c}2014 \\
4)\end{array}$ & 2015 & 2016 & 2017 \\
\hline 1 & 2 & 3 & 4 & 5 & 6 & 7 & 8 \\
\hline \multicolumn{8}{|c|}{ Scope of supply, thousand units } \\
\hline $\begin{array}{l}\text { Agricultura } \\
1 \text { machinery } \\
\text { (mechanica } \\
1 \\
\text { engineering } \\
\text { ) }\end{array}$ & 2284 & 1569 & 1110 & $\begin{array}{l}948 \\
6\end{array}$ & $\begin{array}{l}912, \\
7\end{array}$ & $\begin{array}{l}888, \\
4\end{array}$ & 913,6 \\
\hline \multicolumn{8}{|l|}{ including: } \\
\hline state & 2169 & 1491 & 1055 & $\begin{array}{l}901, \\
2\end{array}$ & $\begin{array}{l}867 \\
1\end{array}$ & 844 & 867,9 \\
\hline $\begin{array}{l}\text { subjects of } \\
\text { small and } \\
\text { medium } \\
\text { businesses }\end{array}$ & $\begin{array}{l}114, \\
2\end{array}$ & 78,5 & 55,5 & 47,4 & 45,6 & 44,4 & 45,7 \\
\hline \multicolumn{8}{|c|}{ Production sphere, billion rubles } \\
\hline $\begin{array}{l}\text { Agricultura } \\
1 \text { product }\end{array}$ & 742 & 1381 & 2588 & 3687 & 5165 & $\begin{array}{l}5505 \\
, 7\end{array}$ & 5654 \\
\hline \multicolumn{8}{|l|}{ including: } \\
\hline $\begin{array}{l}\text { plant } \\
\text { growing }\end{array}$ & $\begin{array}{l}206, \\
2 \\
\end{array}$ & $\begin{array}{l}358, \\
4 \\
\end{array}$ & $\begin{array}{l}619 \\
4 \\
\end{array}$ & 1305 & 1767 & 2010 & 3033 \\
\hline $\begin{array}{l}\text { agriculture } \\
\text { organizatio } \\
\mathrm{n}\end{array}$ & 189 & $\begin{array}{l}294 \\
4\end{array}$ & $\begin{array}{l}485 \\
9\end{array}$ & $\begin{array}{l}974, \\
1\end{array}$ & 1307 & 1474 & 1437 \\
\hline $\begin{array}{l}\text { peasant } \\
\text { (farmer's) } \\
\text { economy }{ }^{1)}\end{array}$ & 17,2 & 64,0 & $\begin{array}{l}133 \\
5\end{array}$ & $\begin{array}{l}330 \\
5\end{array}$ & $\begin{array}{l}460 \\
0\end{array}$ & $\begin{array}{l}536 \\
6\end{array}$ & 577,2 \\
\hline farmings & 153 & $\begin{array}{l}341, \\
5\end{array}$ & 718 & 1264 & 1466 & 1544 & 2620 \\
\hline $\begin{array}{l}\text { agriculture } \\
\text { organizatio } \\
\mathrm{n}\end{array}$ & 147 & $\begin{array}{l}321, \\
2\end{array}$ & $\begin{array}{l}664, \\
1\end{array}$ & 1165 & 1351 & 1417 & 1540 \\
\hline \multicolumn{8}{|c|}{ The transport and logistics sector, million tons } \\
\hline Total & 7907 & 9167 & 7749 & 8006 & 7582 & 7597 & 6957 \\
\hline $\begin{array}{l}\text { of these, } \\
\text { commercial }\end{array}$ & 2372 & 3209 & 3487 & 3443 & 3564 & 3510 & 3661 \\
\hline \multicolumn{8}{|l|}{ including: } \\
\hline $\begin{array}{l}\text { Railway } \\
\text { (cargo } \\
\text { loading) }\end{array}$ & 1047 & 1273 & 1312 & 1375 & 1329 & 1227 & 1106 \\
\hline $\begin{array}{l}\text { The car in } \\
\text { total }\end{array}$ & 5878 & 6685 & 5236 & 5417 & 5041 & 5138 & 4748 \\
\hline $\begin{array}{l}\text { including: } \\
\text { on } \\
\text { commercial } \\
\text { basis }\end{array}$ & 1117 & 1471 & 1204 & 1138 & 1361 & 1423 & 1451 \\
\hline Marine & 35 & 26 & 37 & 16 & 19 & 28 & 19 \\
\hline $\begin{array}{l}\text { Inland } \\
\text { water }^{2)}\end{array}$ & 117 & 134 & 102 & 119 & 121 & 260 & 303 \\
\hline $\begin{array}{l}\text { Air } \\
\text { (transport } \\
\text { aviation) } \\
\end{array}$ & 0,8 & 0,8 & 1,1 & 1,3 & 1,2 & 1,0 & 1,1 \\
\hline \multicolumn{8}{|c|}{ 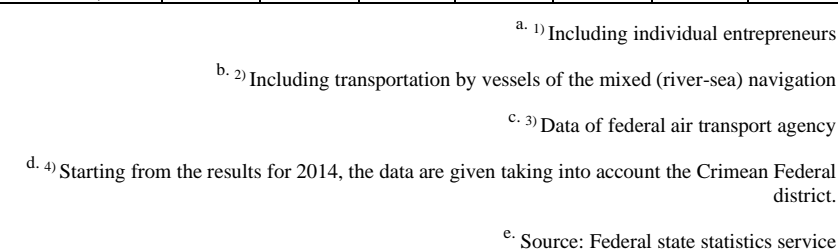 } \\
\hline
\end{tabular}

The analysis of the given indicators testifies to rather spasmodic presence of sector of small and average business in all AIC segments. An important direction of agriculture 
of small and medium businesses" of the state program in the Krasnoyarsk region "Development of investment activity, small and medium businesses".

Priority directions in the implementation of state support measures, in accordance with federal objectives, are the development of infrastructure to support small and medium businesses and the provision of direct financial support to business entities. The existing support mechanisms are aimed, among them, at eliminating the factors constraining the development of entrepreneurship in the region.

According to estimates for 2017, the number of small and medium businesses in the region will be 123.6 thousand $(-0.7$ $\%$ by 2016), including 368 medium businesses, 52,708 small businesses (including micro businesses), 70,855 individual entrepreneurs. The average number of employees of small and medium businesses, including micro businesses (without external part-time workers), will be 224.5 thousand people.

In 2016, the Federal service of state statistics in accordance with the federal law of 24.07.2007 № 209 - FL "About development of small and medium entrepreneurship in the Russian Federation" was carried out a continuous statistical monitoring of the subjects activity of small and medium business, therefore, by the end of 2015, absent statistical information about subjects activity of small and medium business.

In the absence of statistical data, there have been changes in federal legislation related to the clarification of the criteria for attribution to small and medium businesses. By the resolution of the Russian Federation government of 04.04.2016 No. 265 the limit values of the income received from implementation of business activity for each category of subjects in small and medium business added up on all carried-out types of activity and applied on all tax regimes are changed: micro businesses -120 million rubles; small businesses - 800 million rubles; medium businesses -2 billion rubles. These changes led to the redistribution of small and medium businesses in their categories, including the transition of a number of medium businesses in the category of small businesses.

Also, the accounting of small and medium businesses has changed. Since August 2016, accounting is carried out on the basis of the unified register for small and medium businesses formed by the federal tax service (FTS) of Russia. The unified register of subjects for small and medium business is formed on the basis of the data submitted by subjects of small and medium business in FTS of Russia according to the legislation of the Russian Federation about taxes and fees. In case of nonsubmission of data due to the lack of economic activity, the subject is excluded from the register. Data on the number of small and medium-sized businesses registered in the register differ significantly in a smaller way than statistical data (according to the register, the number of small and medium businesses - 107 thousand, according to statistics - more than 125 thousand).

Currently, Krasnoyarsk has support mechanisms that contribute to the development of small and medium-sized agribusiness: 
To date, the main motivation for the development of

- State programs "Development of investment activity of small and medium businesses", "Development of agriculture and regulation of agricultural products, raw materials and food".

- Provision of subsidies and grants.

- Training and mentoring.

- Financial assistance. Any microloans and guarantees.

In order to stimulate the growth of business activity, the creation of new industries in agriculture, promote selfemployment of the regional population in the forecast period, measures are being implemented to financially support small and medium businesses and citizens wishing to engage in business activity in rural areas, in the form of grants and subsidies [16].

The implementation of state support measures in the forecast period will contribute to the turnover growth of small and medium businesses in value terms, as well as an increase in investments in fixed capital of small businesses. The turnover of small and medium businesses (including micro businesses) will increase from 868.3 billion rubles in 2017 to $1,018.1$ billion rubles in 2020. The volume of investments in fixed assets of small businesses (including micro businesses) will increase from 18.4 billion rubles in 2017 to 21.4 billion rubles by the end of 2020 .

\section{CONCLUSIONS}

The formation of a new paradigm for the development of agriculture should be based on existing models of socioeconomic development of regions and the country. The management model of sustainable agricultural development should be based on the principles of state regulation of socioeconomic processes, "combination" of administrative impact and market mechanisms, support for the development of small businesses and social protection of the poor local population. Complex implementation of such principles along with correctly chosen management tools can provide effective satisfaction of population economic interests in combination with increase of managing subjects' efficiency of agrarian production.

The target model "Support of small and medium businesses" takes into account the practical experience of implementing measures to support small and medium businesses at the regional level and is a set of minimum necessary actions of the authorized executive authorities of the Russian Federation subjects, as well as organizations that form the infrastructure to support small and medium businesses and operating on the territory of the Russian Federation subjects [17].

The implementation of the target model is aimed at the formation of the basic infrastructure of business support in the regions, as well as increasing the availability of support measures for existing small and medium-sized businesses and citizens planning to carry out business activities. The implementation of the target model is carried out within the framework of the regional priority project "Improvement of the investment climate of the Krasnoyarsk territory". agriculture in the country is the prospects for the development of small and medium businesses. The agro-industrial complex is a strategically important node, which involves the development of small and medium businesses as one of the priority directions of solving the problem of food security of the state in general and each region in particular [18].

\section{REFERENCES}

[1] E. V. Rudoy, P. M. Fedyaev and E. V. Afanasyev, Main tasks and ways of development of agro-industrial complex on improvement of food supply for the population of the Siberian Federal district, Vestnik OmSAU, 2016,. 2, pp. 268-273.

[2] A. A. Grudneva, Problems of development of small and medium businesses in the agro-industrial sphere, Theoretical and applied economics, 2016, 4, pp. 27-39, DOI: 10.7256/2409-8647.2016.4.21013. URL: http://e-notabene.ru/etc/article_21013.htm

[3] L.Toomsalu, S. Tolmacheva, Vlasov A., and V. Chernova, Determinants of innovations in small and medium businesses : a european and international experience, Terra Economicus, 2019, vol. 17, 2, pp. 112 123.

[4] I. N. Chuev, T. M. Panchenko, V. S. Novikov, O. A. Konnova, N. G. Iraeva and I. S. Karabulatova, 2016, Innovation and integrated structures of the innovations in modern Russia. International Review of management and marketing, 6(1S), p. 238-244

[5] O. N. Berduygina, A. I. Vlasov and E. A. Kuzmin, 2017, Investment public-private partnership, Investment Management and Financial Innovations, 14(3), pp. 189-198. DOI: 10.21511/ imfi.14(3-1).2017.03

[6] V. Fursov, E. Krivokora and W. Strielkowski, 2018, Regional aspects of labor potential assessment in modern Russia, Terra Economicus, 16(4), 95-115. https://doi. org/

[7] O V Zinina, N A Dalisova, N I Pyzhikova and J A Olentsova 2019 Development prospects of the Krasnoyarsk region agroindustrial complex in the export conditions IOP Conf. Ser.: Earth Environ. Sci. 315022068

[8] M G Ozerova, A V Sharopatova and J A Olentsova 2019 Improving the competitiveness of agricultural products as a basis for solving import replacement issues IOP Conf. Ser.: Earth Environ. Sci. 315022026

[9] Ji-Hyeon C., Jang H., Byung-Joon W. Agro-industry Cluster Development in Five Transition Economies // Journal of Rural Development. 2007. № 29(6). S. 85-119.

[10] Galvez-Nogales E. Agro-based clusters in developing countries: staying competitive in a globalized economy. Food and agriculture organization http://www.fao.org/docrep/012/i1560e/i1560e.pdf.

[11] Cao Q.S., Yan Z.W., Chu F., Tang Y.B. The current situation and countermeasure of development of agricultural clusters in China // Jiangsu Agricultural Sciences. 2010. № 6. S. 608-610.

[12] Hazell, P., Poulton, C., Wiggins, S., Dorward, A. (2010). The Future of Small Farms: Trajectories and Policy Priorities. World Development, 38(10), 1349-1361. DOI: 10.1016/j.worlddev.2009.06.012

[13] Johansen, C., Haque, M., Bell, R. et al. (2012). Conservation agriculture for small holderrainfed farming: Opportunities and constraints of new mechanized seeding systems. Field Crops Research, 132, 18-32. DOI: 10.1016/j.fcr.2011.11.026

[14] Murshed-E-Jahan, K., Pemsl, D.E. (2011). The impact of integrated aquaculture-agriculture on small-scale farm sustainability and farmers' livelihoods: Experience from Bangladesh. Agricultural Systems, 104(5), 392-402.

[15] O I Antamoshkina and O V Zinina 2019 A methodology for assessing the prospects of modifying business strategy of an enterprise in the external environment IOP Conf. Ser.: Mater. Sci. Eng. 537042023 capacity of the economy during the implementation of projects of of the United Nations, Rome, 2010. URL: 
[18] G Belyakova, E Stepanova and E Zabuga 2019 High Knowledge Level for an Innovation Cluster Environment Formation in the Russian Federation 20th European Conference on Knowledge Management (ECKM 2019) Edited by Dr. Eduardo Tomé, Dr. Francisco Cesário Dr. Raquel Reis Soares Hosted By UniversidadeEuropeia de Lisboa Lisbon, Portugal 5-6 September 2019 Vol. 1 pp.111-122. 